\title{
2007s-04 \\ Sharing Liability Between \\ Banks and Firms: \\ The Case of Industrial Safety Risk
}

Marcel Boyer, Donatella Porrini

\begin{tabular}{c}
\hline Série Scientifique \\
Scientific Series
\end{tabular}

Montréal

Mars/March 2007

(C) 2007 Marcel Boyer, Donatella Porrini. Tous droits réservés. All rights reserved. Reproduction partielle permise avec citation du document source, incluant la notice (C).

Short sections may be quoted without explicit permission, if full credit, including (C) notice, is given to the source.
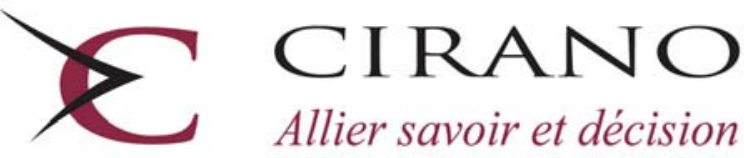

Allier savoir et décision

Centre interuniversitaire de recherche en analyse des organisations 


\section{CIRANO}

Le CIRANO est un organisme sans but lucratif constitué en vertu de la Loi des compagnies du Québec. Le financement de son infrastructure et de ses activités de recherche provient des cotisations de ses organisations-membres, d'une subvention d'infrastructure du Ministère du Développement économique et régional et de la Recherche, de même que des subventions et mandats obtenus par ses équipes de recherche.

CIRANO is a private non-profit organization incorporated under the Québec Companies Act. Its infrastructure and research activities are funded through fees paid by member organizations, an infrastructure grant from the Ministère du Développement économique et régional et de la Recherche, and grants and research mandates obtained by its research teams.

\section{Les partenaires du CIRANO}

Partenaire majeur

Ministère du Développement économique, de l'Innovation et de l'Exportation

\section{Partenaires corporatifs}

\section{Alcan inc.}

Banque de développement du Canada

Banque du Canada

Banque Laurentienne du Canada

Banque Nationale du Canada

Banque Royale du Canada

Banque Scotia

Bell Canada

BMO Groupe financier

Bourse de Montréal

Caisse de dépôt et placement du Québec

DMR Conseil

Fédération des caisses Desjardins du Québec

Gaz de France

Gaz Métro

Hydro-Québec

Industrie Canada

Investissements PSP

Ministère des Finances du Québec

Raymond Chabot Grant Thornton

State Street Global Advisors

Transat A.T.

Ville de Montréal

\section{Partenaires universitaires}

École Polytechnique de Montréal

HEC Montréal

McGill University

Université Concordia

Université de Montréal

Université de Sherbrooke

Université du Québec

Université du Québec à Montréal

Université Laval

Le CIRANO collabore avec de nombreux centres et chaires de recherche universitaires dont on peut consulter la liste sur son site web.

Les cahiers de la série scientifique (CS) visent à rendre accessibles des résultats de recherche effectuée au CIRANO afin de susciter échanges et commentaires. Ces cahiers sont écrits dans le style des publications scientifiques. Les idées et les opinions émises sont sous l'unique responsabilité des auteurs et ne représentent pas nécessairement les positions du CIRANO ou de ses partenaires.

This paper presents research carried out at CIRANO and aims at encouraging discussion and comment. The observations and viewpoints expressed are the sole responsibility of the authors. They do not necessarily represent positions of CIRANO or its partners. 


\title{
Sharing Liability Between Banks and Firms: The Case of Industrial Safety Risk ${ }^{*}$
}

\author{
Marcel Boyer ${ }^{\dagger}$, Donatella Porrini ${ }^{\ddagger}$
}

\begin{abstract}
Résumé / Abstract
Nous caractérisons les distortions dans le partage de responsabilités entre banques et firmes qu'implique l'implémentation imparfaite des politiques gouvernementales. Ces distortions découlent de la présence de risque moral et de sélection adverse, de l'utilisation de fonctionsobjectifs par les firmes et les banques diffèrentes de la fonction de bien-être social, et de la difficulté des cours de justice d'évaluer le niveau de précaution exercé par les firmes. Nous montrons l'existence de divers cas où le partage de responsabilités est supérieur ou inférieur au partage optimal en information et implémentation parfaites. Nous obtenons des résultats de statique comparée illustrant la sensibilité du partage des responsabilités aux paramètres pertinents à la détermination d'une politique optimale de protection environnementale ou de prévention d'accidents industriels.
\end{abstract}

Mots clés : partage de responsabilités, environnement, prévention, risque moral, sélection adverse, principal-agent.

We characterize the distortions in environmental liability sharing between firms and banks that the imperfect implementation of government policies implies. These distortions stem from three factors: the presence of moral hazard, the use of objective functions by firms and banks that differs from the social welfare function, and the difficulty for the court to assess the safety care level exerted by the firms. We characterize cases where the liability sharing factor is above or below its full information perfect implementation level. We derive comparative statics results indicating the sensitivity of the liability sharing factor to changes in some parameters relevant for characterizing the optimal policy toward environmental protection or the prevention of industrial accidents.

Keywords: liability sharing, industrial/environmental liability, safety care, moral hazard, principal-agent.

Codes JEL : D82, G32, K13, K32, Q28

\footnotetext{
* We are grateful to Eric Gravel for research assistance. This paper has appeared in Boyer, M., Hiriart, Y. And D. Martimort (editors), Frontiers in the Economics of Environmental Regulation and Liability, Ashgate Pub. 2006 (pp. 311-341).

† Bell Canada Professor of Industrial Economics, Université de Montréal, CIRANO and CIREQ Fellow, address: CIRANO, 2020 rue University, bureau 2500, Montréal (Québec), H3A 2A5; e-mail: marcel.boyer@cirano.qc.ca.

${ }^{\ddagger}$ Istituto di Scienze Economiche e Statistiche, Università degli Studi di Milano, Italy, e-mail: donatella.porrini@unimi.it.
} 


\section{Introduction}

The determinants of industrial or environmental accidents are numerous and their interactions are complex. To design and implement proper control policies to reduce the probability and severity of those accidents, those determinants and their interactions must be better understood. We consider in this paper that those determinants or factors can be regrouped into three different sets: technological, eventual, and organizational. The first set regroups all factors that are directly linked to the characteristics of the products being handled, both inputs and outputs, and their current production and distribution technologies. Clearly, handling relatively unstable, harmful or explosive chemicals is intrinsically more dangerous and producing or distributing those products by using technologies that are relatively labor intensive or through urban areas or on public transportation networks is also intrinsically more dangerous. The second set of determinants or factors includes exogenous and in part uncontrollable purely random natural events such as lightning, flooding and even residual unavoidable human errors, which may ignite a process leading more or less inexorably to an accident. Finally, the third set contains the organizational characteristics which may contribute to the occurrence of a severe accident by allowing more of less control, coordination or timely information transmission by and among agents who may be called "stakeholders" in the occurrence of industrial or environmental accidents. This paper deals with this third set, namely the organizational factors which include among others the institutional characteristics and informational asymmetries which constitutes significant background features.

More precisely, we study the impact of different institutional and informational constraints in the implementation of a public policy aimed at preventing environmental or industrial accidents. The most important constraints to be taken into account are: limited liability (judgement proofness) of firms; limited capacity of governments to intervene in business decisions and transactions, which requires that governments use policy instruments that are either of the ex-ante regulation 
type, or of the ex-post liability type, including extended liability and financial responsibility, or of both types; limited power of the court system to search and find all the facts relevant to a judgement; asymmetric information between the agents, namely governments, firms, banks, and courts, whose decisions and behavior may have an impact on the observed probability and severity of environmental or industrial accidents.

We discuss in the following sections the institutional frameworks of the American and European liability systems, the specific roles of the four main actors in the determination of industrial/environmental accidents and the relevant academic literature, before proceeding in section 4 with the presentation of our model followed by a section where the main results are discussed. We conclude in section 7 with some policy recommendations.

\section{The Internalization of Environmental Damage in the U.S. and Europe through Extended Liability and Financial Responsi- bility}

The term 'financial responsibility' refers to the set of instruments with which potential polluters can demonstrate ex ante that their financial resources are adequate for the restoration of environmental damage they may cause. In one practical application, financial responsibility requires that the authorization to carry out production activities in risky sectors be restricted to firms who can demonstrate an appropriate financial or insurance coverage for future obligations resulting from the assignment of environmental liability. ${ }^{1}$

\footnotetext{
${ }^{1}$ Financial responsibility includes various kinds of instruments: letters of credit and surety bonds; cash accounts and certificates of deposit; self-insurance and corporate guarantee (Boyd, 2002). Letters of credit and surety bonds are purchased from banks or insurance companies; they require the latter to pay a third party beneficiary (often the government) under specific circumstances, such as the failure of the purchaser to perform certain obligations. Cash accounts and certificates of deposit place cash or some other form of interest-bearing security into accounts that are assigned or made payable to a regulatory authority. Companies with relatively deep pockets may self-insure to satisfy coverage requirements by demonstrating sufficient financial strength. Finally, a corporate guarantee allows another firm, such as a parent company, to satisfy the coverage requirement; financial guarantors must then explicitly agree to cover the liabilities of the firm.
} 
Financial responsibility has been widely applied in the United States since the 1980s within the framework of the liability assignment system for environmental damage, particularly in the U.S. Comprehensive Environmental Response, Compensation and Liability Act (CERCLA) that states that the owners and operators of a facility causing an accident are strictly liable for the costs involved in cleaning up the contaminated sites and in compensating the victims. ${ }^{2}$

The U.S. experience shows that financial responsibility may be a (sometimes necessary) complement to legislation on liability assignment of environmental damage. It is usually needed to ensure that the damaged natural resources are reclaimed. Its different applications all stem from a common motivation, which is to ensure the proper internalization of the financial burden engendered by polluters in order to indemnify victims and discourage various forms of environmental deterioration.

As in the U.S. system, the proposed EC system considers the need for instruments that foster the internalizing of environmental damage in cases of insolvency and judgment-proofness of the liable parties. In the wording of the Proposal: ${ }^{3}$ "The insolvency of operators is one factor that may hinder cost recovery in line with the 'polluter pays' principle by competent authorities, but the impact of this may be limited by adequate financial insurance of potential damage" (page 4, point 2). Thus the EC legislator recognizes an important role for financial institutions, although it does not specifically define any compulsory financial security in order to meet the flexibility requirements of the new liability system. In fact, the Proposal states that "Financial assurance of environmental liability is beneficial for all stakeholders: for public authorities and the public in general, it is one of the most effective, if not the only, way of ensuring that restoration actually

\footnotetext{
${ }^{2}$ Financial responsibility is also provided for by CERCLA, by the Safe Drinking Water Act (SDWA), by the Outer Continental Shelf Lands Act (OCSLA), and by the Surface Mining Control and Reclamation Act (SMCRA). Moreover, it is part of the Resource Conservation and Recovery Act (RCRA) and of the Oil Pollution Act (33 U.S.C. $§ 2716$ of 1990). Under CERCLA, the Environmental Protection Agency (EPA) can proceed promptly with the clean up of contaminated sites with funding from the Hazardous Substances Response Trust Fund, commonly known as the Superfund. The fund is financed through a combination of federal appropriations, industry taxes, and penalties imposed under judgments entered against responsible parties.

${ }^{3}$ Proposal for a Directive of the European Parliament and of the Council on Environmental Liability with regards to the Prevention and Remedying of Environmental Damage, COM (2002), 17 final, Brussels, January 23, 2002.
} 
takes place in line with the 'polluter pays' principle; for industry operators, it provides a way of spreading risks and managing uncertainties; for the insurance industry, it is a sizeable market" (page 7 , point 4).

But while in the U.S., due to the legal provisions, financial responsibility has evolved to provide a wide array of financial instruments tailored to individual firms and regulatory needs, in the EC this kind of instrument has a corresponding importance but relatively little diffusion. In fact, the White Paper $^{4}$ ( $\$ 4.9$ "Financial security") contains the following statement: "When looking at the insurance market - insurance being one of the possible ways of having financial security, alongside, among others, bank guarantees, internal reserves or sector-wise pooling systems - it appears that coverage of environmental damage risks is still relatively undeveloped, but there is clear progress being made in parts of the financial markets specializing in this area." The imposition of such instrument also seems to be delayed in time, as indicated by the statement that "... the EC regime should not impose an obligation to have financial security, in order to allow the necessary flexibility as long as experience with the new regime still has to be gathered. The provision of financial security by the insurance and banking sectors for the risks resulting from the regime should take place on a voluntary basis." This, however, disregards the fact that financial responsibility instruments have already been made mandatory within individual Member States. ${ }^{5}$

From an economic point of view, the enforcement of financial responsibility ensures that the expected costs related to environmental risks are recorded in the firm's balance sheet and accounts. Since financial guarantees are purchased from banks or insurance companies, a contract relation is established that makes the latter keen on protecting their investment, for instance by

\footnotetext{
${ }^{4}$ White Paper on Environmental Liability, COM (2000), 66 final, Brussels, February 9, 2000.

${ }^{5}$ For example in Italy, the Ministero dell'Ambiente, in a decree of October 8, 1996, defined the method for granting financial guarantees in favor of the State by companies that carry out waste transportation activities related to reclaiming, restoration of site conditions, waste transportation and disposal, as well as the reimbursement of any further damage caused to the environment. Another example is the Flemish experience - in particular the proposals of the Interuniversity Commission for the revision of environmental law in the Flemish region, which has provided for elaborate provisions concerning financial guarantees (Faure and Grimeaud 2000).
} 
monitoring the production activity of their corporate customers. As in the economic models of lenders' liability found in the literature, the bank, acting as principal in a financial responsibility regime, is encouraged to monitor the environmental risk prevention activity of its corporate customers. The agent firm, in turn, pays to the principal the cost associated with its risk level (through possibly the cost of the loan), and is therefore encouraged to adopt preventive measures to reduce its risk and, as a result, its total borrowing costs.

In this respect, the "financial guarantors" may provide a remedy to information asymmetry issues - in particular those involving moral hazard - through monitoring. They may also help addressing issues related to adverse selection, through contract design and by setting an appropriate loan cost, thereby offering lower cost guarantees to firms that make less risky choices from an environmental standpoint and to those that implement prevention schemes (Feess and Hege 2000, 2003).

The efficiency of extending liability to the firm's major partners, as part of the broader policy issue of preventing environmental and/or industrial accidents, has been recently addressed in the literature, as a principal-agent problem between a bank or financier and a firm. ${ }^{6}$ Extending environmental liability becomes a crucial factor once a firm has reached the stage of judgmentproofness (Shavell 1986) a problem which arises when identified polluters prove unable to pay for the damages they caused. ${ }^{7}$ Given that they may fail to pay the full cost associated with the environmental damage, firms face weaker incentives to implement preventive measures at an efficient level.

\footnotetext{
${ }^{6}$ Numerous contributions have appeared recently in the literature addressing the question of lenders' liability: see for instance Beard (1990), Pitchford (1995, 2001), Heyes (1996), Boyer and Laffont (1996, 1997), Boyd and Ingberman (1997), Balkenborg (2001), and Lewis and Sappington (2001), Boyer and Porrini (2004), Gobert and Poitevin (2004).

${ }^{7}$ Judgment-proofness is not necessarily connected with firm size: "History has unfortunately shown that even companies with limited financial means may cause huge environmental damage and may thereafter be judgmentproof. Moreover, the insolvency risk may even arise with larger companies since almost all (larger) companies are organized as legal entities and therefore enjoy the benefits of the limited liability of the corporation" (Faure 2001, p. 192).
} 
A particular case of extended lenders' liability stems from significant jurisprudence in the United States. Under the CERCLA-based system of strict liability of the polluting firms, the notion of owner and operator used in the wording of the law was gradually extended to include lenders who were particularly active in supervising the firm's operations. In so doing, the court have been instrumental in finding deep-pocket parties to compensate victims and pay for clean-up costs caused by insolvent firms. ${ }^{8}$ In the case United States v. Mirabile (Environmental Law Reports 20, 994 (E.D. Pa 1985)), the bank was found liable for the damage because the Court found that it had been significantly involved in the supervision of the firm's operations. The Court stated that in this case, the firm's lenders could be considered as operators and, as such, the so-called "secured creditor exemption clause" was not applicable, and therefore that the bank was liable for the damage under CERCLA regulation. In another case, United States v. Maryland Bank and Trust (632 F. Supp. 573 (d. Md. 1986)), the Court stated that the bank was liable for the decontamination costs based on the fact that it became the owner of the plant after the closing of the firm before the damage was identified. In contrast with the previous case, no consideration was given to the fact that the bank had been involved or not in the decisions made with respect to the polluting substances. Rather, the lender's liability was established on the sole ground that the bank had become the owner of the property. Finally, in the case United States v. Fleet Factors Corp. (901 F. 2d 1550 (11th Cir. 1990), cert. Denied, 498 U.S. 1046 (1991)), the bank was deemed liable for the decontamination costs based on the fact that its financing of the firm had conferred it the ability to influence management, even if it had not been directly involved in the firm's operations. This rule would provide for lenders to be considered parties to the management of the firm simply because, in granting the loan, they could if they wished force their clients to carry out preventive actions against environmental abuses and/or may review their preventive practices.

In this vein, it is possible to define a form of "extended principal-agent liability," under which liability is shared between the firm and its financier, thereby giving financial institutions an

\footnotetext{
${ }^{8}$ See Boyer and Porrini (2002) for a discussion of that jurisprudence.
} 
incentive to properly identify and monitor risky firms. This is the modeling strategy we use in this paper. It implies an active preventive role for financial institutions through financial responsibility in the spirit of the proposed common liability system mentioned in a European Community Directive. ${ }^{9}$ Imposing liability on financial institutions is thus not seen any more simply as a way to relax the firms' resources constraint. Rather, in the new system, the legislator will delegate to financial institutions part of its control upon the firms' preventive behavior by inducing them to internalize environmental damage.

Rather than an extended liability system, we will consider a liability sharing system under which the bank is responsible for a fixed part (percentage) of the damage caused - even in the case where the firm actually has the financial resources to cover more than its complementary part of the damage. With the implementation of a liability sharing system the banks are called upon to influence the firms' environmental prevention activities through different forms of monitoring or incentive financial contracts when the banks suffer from an asymmetric information structure regarding the firms' preventive activities.

However the principal-agent relationship between the bank and the firm is only part of the complex network of relationships that characterizes the business environment of a firm whose activities give rise to a probability of industrial/environmental accident. Thus, we will also consider explicitly the behavior and decisions of other parties, such as governments and courts. In a sense, the role of providing incentives for preventive environmental care by monitoring firms' activities is shared between regulatory bodies, firms and courts. ${ }^{10}$

\footnotetext{
${ }^{9}$ The European Parliament and the Council, Directive of the European Parliament and of the Council on Environmental Liability with regard to the Prevention and Remedying of Environmental Damage, Joint text approved by the Conciliation Committee, Brussels, 10 March 2004.

${ }^{10} \mathrm{An}$ important point is then the comparison of ex ante and ex post instruments; see Boyer and Porrini (2001, 2004).
} 


\section{Environmental Protection Policy: The Roles of Government, Financial Institutions, Firms, and Courts}

The environmental economics literature on lenders' liability mainly applies the principal-agent framework to the relationship between firms and financial institutions. In this paper we extend the concept of principal-agent liability to include other relationships that are important determinants of the industrial/environmental safety decisions aimed at preventing environmental accidents.

The first kind of relationship is the one between firms and financial institutions. Our model will take into account the recent trend described above with respect to the instrument of financial responsibility. Thus insurance companies and banks can be called upon to provide financial guarantees for firms that operate in risky sectors. Informational asymmetries are present in this relationship and want to model the monitoring role that can be played by the financial institutions regarding the prevention care activities implemented by firms.

The second kind of relationship is the one between firms and the government/legislator. The government/legislator determines a recommended level of safety and sets the rule to share liability between the firm and the financial institution. Unlike other contributions, such as Balkenborg's (2004), which consider a punitive liability that can exceed the damage costs, our model is built on a full liability that covers all but only the damage costs. In the model, the sharing rule takes into account the incentives towards the optimal level of prevention in a framework that is again characterized by the presence of informational asymmetries about the prevention decisions of the firms.

Finally, the third kind of relationship is the one between firms and courts. The courts are called upon to decide if and when firms are negligent in choosing a level of prevention that is lower than the level recommended by government. Also, financial institutions may have an interest in 
suing firms that are (or appear to be) guilty of insufficient preventive action, with the intent of recovering from them their part of the shared burden.

This model developed here includes the three types of relationships described above between the four actors involved: firms, financial institutions, government/legislator, and courts. In the literature addressing the choice of instruments to implement an environmental policy, the focus is generally on one of these relationships only. But in a realistic framework meant to design an optimal policy, it is clearly necessary to consider the roles of all four actors, in particular if one wishes to account for the optimal delegation to financial institutions of the monitoring of prevention activities realized by the firms.

Thus although this paper will not explicitly address the issue of the comparison between $e x$ ante and ex post regulations, the role of the courts in evaluating (ex post) the firm's behavior is connected to the command-and-control standards set by ex ante regulation. In this sense, the role of providing incentives for preventive care by the means of monitoring activities is shared between regulatory agencies and the courts (Boyer and Porrini 2001). Working in this direction, Boyer and Porrini (2004) compare ex ante and ex post environmental regulation by modeling a liability system, where liability is extended to the financial partners of the firm when the firm goes bankrupt following an environmental accident, and an incentive regulation system, where the environmental protection agency may be "captured" by the regulated firms. Their model integrates the following variables and features, whose effects on the choice of instrument for environmental protection is characterized: limited liability; the cost of low and high levels of preventive care; the non observability of care; the social cost of public funds; the (net) profitability of the firm; the level of damages if an accident occurs; and finally a regulatory capture factor. They show that a relatively large cost of care favors the extended liability regime because the captured regulator regime would imply too much care, or too few environmental accidents, and too much financing of risky business, that is, an over-development of environmentally risky industries. This is due to the fact that the social value of the informational rents so allowed 
is not large enough to compensate for the social cost of the extra care activities. They also show that a relatively low cost of public funds, i.e. a relatively efficient (nondiscretionary) taxation system, favors the captured regulator regime because the extended lender liability regime would imply too little care and too little financing. This is because the benefits of a reduced expected cost of environmental accidents are not large enough to compensate for the loss of profits (informational rents), whose social cost is small when the cost of public funds is low. Finally, they show that a larger regulatory capture factor favors the extended liability regime: the captured regulator induces too much preventive care and hence too few accidents, allowing the firm to reap a costly informational rent. Hence, the best instrument in terms of social welfare may not be the one which ensures the better environmental protection as measured by the lower probability of environmental accidents. In a similar vein, Hutchison and van't Veld (2004) consider a context where some care activities (unobservable) reduce the probability of accident while others (observable) reduce the level of damage if an accident occurs. In such a context, extended liability improves welfare but does not induce the first-best levels of care. With free entry and exit in the industry, extended liability generates too much exit (although second-best optimal given the levels of care). The authors show that if the regulator is constrained to one instrument only, then direct regulation of the observable type of care strictly welfare dominates extended liability.

Referring to the law and economics literature, principal-agent liability relates to cases where instead of a single actor as injurer, harm is caused by an individual or a firm that is under the control or supervision of someone else. Principal-agent schemes are applied to analyze cases in which liability is extended from the person that directly caused the damage to a party that is in some sense related to that person. This is the so-called "secondary" or "vicarious" liability (Sykes 1984; Kornhauser 1982), such as that of the parents who are deemed liable for damage caused by their children, or the employer who is deemed liable for the damage caused by the activities of its employees. Some aspects remain to be developed in modeling this form of delegated control, including the presence and possible effects of monitoring costs (Dari Mattiacci 
and Parisi 2004) as well as the definition of the optimal sharing rule between the principal and the agent in terms of ex ante incentives to undertake the optimal level of prevention activities.

In Polinsky (2003) the assignment of liability to the principal is crucial to achieve the optimal level of prevention in three cases. The first case is when the agent's risk aversion lowers the optimal level of liability that the agent himself should bear as for instance, in product liability analysis when the harm is accidental in character. The second case relates to the principal's formal monitoring role when it is difficult to determine whether the agent caused harm; in such circumstances, a strictly liable principal has a strong incentive to control her agents' preventive behavior. The third case is the judgment-proofness of the agent, which induces him to carry out inadequate prevention activities and, again, renders important the monitoring role of a liable principal that will be called upon to compensate part of the damage.

Among other contributions, Newman and Wright (1990) address the problem of defining a principal-agent liability framework where moral hazard is also being considered. In particular, the authors examine the socially optimal level of prevention compared with the level achieved under strict liability in the case where an environmental/industrial accident is caused by employees' action. Given that the preferences of the employee/agent differ from those of the employer/principal and the agent's prevention activities are unobservable, a moral hazard problem arises and the principal's strict liability will influence the choice of employment contract offered.

The law and economics literature represents principal-agent liability as a framework where maximizing agents choose their preventive care level under the monitoring activities of some principal (Shavell 2004). In these models there is no room for considering how the agent's prevention decision may be influenced by factors other than the maximization hypothesis and the principal's influence. Daughety and Reinganum (2003) proposed to widen the standard law and economics literature framework by assuming that market and the tort system interact to affect the decision about prevention care level with reference to product liability. In particular, their analysis 
includes an endogenously-determined fixed-cost component to prevention that comes from the characteristics of the output market, the relevant litigation costs, a representation of victims as a consumer, a group of consumers or third parties, and a variety of imperfectly competitive market structures. ${ }^{11}$

In this paper we analyze extended liability and consider as liable parties the financial institutions that provide financial resources for production activities that may be environmentally risky. Thus with respect to the law and economics literature described above, we widen the traditional framework by adopting the legislator's point of view which, in these cases, is to determine what mix of liability to impose on the principal and the agent in order to maximize a social welfare criteria. However this maximum welfare depends upon the incentives the firm as the agent faces given its financial contract with the bank. When the firm's preventive care behavior is observable by the bank, the financial contract can impose a specific level of preventive measures as a condition for financing the firm. In general, social optimum is achieved in a full information setting by having one party or the other bear full responsibility for the damages. However, if the firm is subject to limited liability, the damage may not be fully internalized when holding the firm solely liable for the accidents it causes and, therefore, some liability should be assigned to the bank as principal in order to achieve socially optimal care.

The case of incomplete information is considered in Segerson and Tietenberg(1992). They assume the existence of moral hazard related to the contract with standard debt and risk sharing. In this case, the financial contract cannot directly depend on the firm's prevention effort. It is thus socially optimal to assign liability to the firm, i.e. to the informed party, until the damage cost is fully internalized. However, within a system of limited liability this may be unenforceable and may impede full damage internalization, leading to a sub-optimal prevention effort. The authors suggest making up for the limited liability problem by defining non-monetary penalties, including criminal prosecution for decision-makers and managers, in case of accident.

\footnotetext{
${ }^{11}$ See Woodfield (1004) for a discussion of liability Internet Service Providers may incur for transporting content material which violates copyrights.
} 
Pitchford (1995) develops a model of a judgment-proof firm, a lender and a victim in which a full lender liability policy can increase accident frequency and reduce efficiency. Under moral hazard and limited liability, the prevention effort is sub-optimal, hence the search for some liability sharing between the firm and its lender as a mechanism to bridge in part the gap between actual and optimal unobservable efforts to reduce the probability of accident, whose damage is known. The loan contract considered by Pitchford provides for payments conditional upon the occurrence or not of an accident. The prevention effort level chosen by the firm depends then on the difference between the loan reimbursement by the firm in the two states, accident and no-accident. If the creditor or lender "cannot observe the precautionary choice undertaken by the firm, and if that firm is potentially judgment-proof, then increasing the liability of the creditor can lead to an increase in the probability of accident" (page 1182), due to the fact that the creditor, requiring that a proper insurance-like premium be paid by the firm in the no-accident case reduces the difference between the firm's profits in the two states and therefore reduces incentives for care: the firm gets no profit in the accident case and a reduced profit in the no-accident case due to the higher insurance premium. Pitchford concludes that the optimal lenders' liability level from an accident prevention standpoint is equal to the amount of the firm's available capital, that is, the project value added plus the equity invested. If lender liability is lower or higher than this level, the contract ends up providing an incentive for the firm to lower its prevention effort.

Boyer and Laffont (1997) studied the lenders' liability issue with a two-period model, including a refinancing decision in the second period. This decision is made in an incomplete information setting, which may alternatively take the form of moral hazard on the prevention effort and of adverse selection on the profitability of the firm. The firm is liable for the accident damage up to the value of its assets and the bank is liable for the residual damage. In the first period, the bank offers a loan contract. If the firm accepts, it makes a prevention effort and achieves a first period profit. At the beginning of the second period, the bank must decide whether to refinance the firm or not, a decision which is used in the adverse selection case, to elicit truthful 
revelation of the first period profit level. If the firm is refinanced, another profit is realized and an environmental accident may or may not occur. In the moral hazard case, Boyer and Laffont conclude by advising against full lender liability, i.e. a liability rule by which, following a major accident which makes the firm bankrupt, the bank pays the total amount of damage and recovers whatever it can from the firm's assets. The private contract solution approaches the socially optimal solution if the bank's liability is defined as a share of such damage. The authors derive a formula for the optimal bank extended liability share, which depends on the model's parameters, and particularly upon the cost of public funds.

Hiriart and Martimort (2004) consider the optimal regulation of a risky project where a buyer (principal) has a contract with a seller (agent). The information on the level of safety care exerted by the agent is private to the agent (moral hazard). The authors derive conditions under which extending liability to the principal (buyer) improves social welfare. They show that if the principal has all the bargaining power, then extended liability favors the internalization of environmental damage and so improves welfare. However, when principals are competitive, extending liability has no value under complete contracting. But if the buyer-seller relation is plagued by adverse selection problems, then extending liability can again contribute to raising welfare.

\section{The Model}

We consider that safety activity levels and therefore environmental or industrial accidents are the result of interactions between, and choices made by four actors: the government, the firm, the financier, and the court. We model the role of each actor as follows.

The government decides on the liability system, that is the liability rules and the standards for safety. The liability system may take different forms combining strict and/or negligence based liability, joint and several and/or distributed liability between the different parties. The 
safety standards are also determined by the government and they stipulate the proper or socially desirable behavior recommended to or imposed on firms. As discussed above, the jurisprudence of extended lender liability and financial responsibility requirements in the US under CERCLA, in Canada and in Europe, can be considered as different forms of shared liability. Building on such jurisprudence, we model the government role as maximizing a social welfare function in setting a (strict) liability sharing formula for accident damage between the bank and the firm, as well as setting safety care standards for the firms. In exchange for its involvement in covering the cost of accidents as a deep pocket provider, the bank will be given a right to sue the firm for negligence in order to recuperate some or all its accident liability costs.

The firm decides on care activities, that is, the design and implementation of a safety program of self-protection or care activities, which can reduce the probability of an accident. ${ }^{12}$ In most cases, the safety plan itself can be considered as observable by all parties but its implementation is much more difficult to observe and must therefore, at least to some extent, be considered as unobservable by external parties. We therefore consider a moral hazard context where the firm chooses the level of care, which is a private information of the firm. Under the government chosen strict liability sharing formula, the firm is strictly responsible for its share of the cost of an accident and for reimbursing the bank's share if it is found guilty of negligence.

The financial institutions (we will refer to those institutions as banks although in many cases they could be insurers or other financial syndicates) make possible the operations of the firm and, through their involvement in the firms' affairs, undertaken to protect their financial interest (loan, equity, and guarantees), can be considered as potentially efficient supervisors of the firm's safety care program. In the Fleet Factor case, ${ }^{13}$ the judge wrote:

"Although similar, the phrase 'participating in management' and the term 'operator'

\footnotetext{
${ }^{12}$ We do not consider here self-insurance activities which could reduce the cost or severity of an accident if and when such an accident occurs.

${ }^{13}$ United States v. Fleet Factors Corp. (901 F. 2d 1550 (11th Cir. 1990), cert. Denied, 498 U.S. 1046 (1991)). For a discussion of that case, see Boyer and Laffont (1996).
} 
are not congruent. Under the standard we adopt today, a secured creditor may incur ... liability without being an operator, by participating in the financial management of a facility to a degree indicating a capacity to influence the corporation's treatment of hazardous wastes. It is not necessary for the secured creditor to actually involve itself in the day-to-day operations of the facility in order to be liable - although such conduct will certainly lead to the loss of the protection of the statutory [secured creditor] exemption. Nor is it necessary for the secured creditor to participate in management decisions relating to hazardous waste. Rather, a secured creditor will be liable, if its involvement with the management of the facility is sufficiently broad to support the inference that it could affect hazardous waste disposal decisions if it so chose. We therefore specifically reject the formulation of the secured creditor exemption suggested by the district court in Mirabile."

We model the role of the bank as financing the firm through a loan contract. Under the government chosen strict liability sharing formula, the firm is responsible for its share of the cost of an accident. However, to represent the bank monitoring capacity, we assume that the liability rule allows it to sue its client firm for negligence in order to recover its share of the accident cost, if it thinks that the firm has been careless in preventing accidents, that is, has been negligent by exerting a level of care lower than the level required by the government determined standards. If the bank decides to sue the firm following an accident, then the case is argued in court.

The court is responsible for deciding on liability or breach of contract in litigation cases. The court is therefore seen as in part responsible for implementing the government policy regarding the liability sharing formula and the safety care standards. In so doing, the court imperfectly assesses the level of care exerted by the firm and finds the firm guilty of insufficient care or negligence if this assessed level is lower than the level required by the safety care standards set by the government. If found guilty, the firm either reimburses the bank for the latter's share of 
the cost of the accident if it can do so or goes bankrupt if it cannot. ${ }^{14}$

The game unfolds as follows. The government first decides on the liability sharing rule and the level of safety care standard: in so doing, it makes the firm strictly responsible for a share of $\alpha \%$ of the cost of an industrial accident while it makes the bank strictly responsible for a share of $(1-\alpha) \%$ of that cost, including both clean-up costs and compensation for victims. We will assume that the cost of an accident is known to be $L$. In spite of the fact that liability is strict in the sense that payments for damages are made in the above proportions to affected parties, the government also sets a minimum standard $s$ for the level of safety a firm should undertake. The standard $s$ is legally enforceable by courts in the following sense. Given the occurrence of an accident generating damages $L$, the bank can sue the firm in court to recuperate its part $(1-\alpha) L$ of the cost of an accident, which, under the strict liability rule, it has already paid in lieu of clean-up costs or compensation to the victims.

Although the level of safety care exerted by the firm is a private information of the firm, the bank is allowed to sue the firm in case of an accident to recuperate its share of the cost. In order to induce the firm to exert a proper level of care, the bank chooses the probability $\nu$ with which it will sue the firm in case of accident and in so doing incurs a cost $C(\nu)$. This cost corresponds to maintaining within the bank a legal apparatus capable of launching court cases and arguing negligent behavior by client firms responsible for accidents; the expected number of such cases depends directly on the probability $\nu$. Litigation costs supported by the firm are simply $C_{F}$ and are assumed to be incurred only if the firm is sued. If the court finds the firm guilty of an insufficient level of safety care, the firm must compensate the bank for the latter's share of the cost of the accident if it can do it (if the firm is solvent) and goes bankrupt if it cannot, in which case the bank seizes the firm's assets but cannot recuperate the residual part of the cost it has

\footnotetext{
${ }^{14}$ There is a fifth group of stakeholders in the determination of the probability and severity of accidents, namely the customers of the firm. Insofar as these customers internalize or not in their buying behavior the industrial or environmental risk that the products they buy represent or cause, they in a sense contribute to the occurrence of such accidents. Boyer, Mahenc and Moreaux (2004) develop an analysis of the impact of the environmental awareness of buyers. We do not consider such an impact in this paper.
} 
incurred.

To avoid the daunting task of explicitly modeling the process by which the firm is found guilty or not, we adopt a simple reduced form description of the court's complex and imperfect process. We assume that given $s$ and $q$ there is a probability denoted by $P(q, s) \in[0,1]$ that the firm will be found guilty for violating the recommended standard. For example, the court cannot perfectly observe the level of care but rather can observe a signal $\tilde{q}$ of the firm's care level with $E(\tilde{q})=q$ (imperfect but unbiased verifiability). We assume that the court's complex and imperfect process is such that the probability $P(q, s)$ is decreasing at a decreasing rate as the firm exert more safety care $\left(P_{q}<0, P_{q q}>0\right)$. We also assume that a tightening of the government determined standard $s$ increases ceteris paribus the probability that the firm will be found guilty $\left(P_{s}>0\right)$.

Hence, the firms are subject to both a strict liability rule for $\alpha \%$ of the cost of an accident and a liability for negligence rule. It is important to notice though that the liability for negligence, which may reach $(1-\alpha) L$ for fully solvent firms and less for judgement proof firms, is incurred only if the bank decides to sue the firm and the court finds the firm guilty, which occurs under imperfect observation of the level of care exerted by the firm. ${ }^{15}$ Firms and banks negotiate a standard Townsend-Gale-Hellwig loan contract. We assume that the firm needs a loan of $K$ to operate. The firm invests the amount borrowed $K$ in a risky project. The project generates profits of $\pi_{1}$ with probability $\mu$ and $\pi_{2}$ with probability $1-\mu$, with $\pi_{2}>\pi_{1}$. An industrial/environmental accident with loss $L$ occurs with probability $p(q) \in(0,1)$ with $p(q)$ decreasing and convex $\left(p^{\prime}(q)<0\right.$ and $\left.p^{\prime \prime}(q)>0\right)$. The amount to be repaid by the firm to the bank is simply $(1+r) K$ where $r$ is the competitive interest rate for the risk class the firm and

\footnotetext{
${ }^{15}$ This modeling strategy differs from the more usual negligence rule under which non-negligent firms are exempt from liability. See for instance Innes (2004) for a model where the government chooses in an integrated way the liability design, enforcement, and regulatory policy when the probability of accident depends on care activities. He shows that the ex-ante regulation of care may be more efficient than ex-post liability even if monitoring care is relatively expensive. See Boyer, Lewis and Liu (2000) for a model where the cost of monitoring affects the setting of standards for care. See also Shavell (1993), Viscusi (1989), and Boyer and Porrini (2001) for comparisons between ex-ante regulatory policies and ex-post liability schemes.
} 
the industry belong to. ${ }^{16}$

We solve the above three stage game by backward induction as we are looking for subgame perfect equilibria. In stage 1 , the government sets the values of $\alpha$ and $s$ to maximize social welfare. In stage 2, the firm and the bank negotiate a loan contract $(r, K)$ and the bank announces its choice of $\nu$, the probability with which it will sue the firm in case of an accident. This probability is set before observing whether an accident occurs or not, and the bank is committed to apply this probability of suing the firm. The firm, knowing $\nu$, chooses the safety care level $q$ at cost $Q(q)$ (we assume $Q^{\prime}(q)>0$ and $Q^{\prime \prime}(q)>0$ ), implying a probability of accident of $p(q)$. The total amount to be paid by the firm to the bank will therefore depend on both $\nu$ and $q$, as well as on $\alpha$ and $s$. In stage 3 , all actors observe whether an accident occurs or not. If an accident occurs, the bank sues the firm with probability $\nu$; if the bank sues the firm, the court is called into play and finds the firm guilty of negligence with probability $P(q, s)$, in which case the firm makes the additional payment $(1-\alpha) L$ if it can do so and otherwise go bankrupt while its assets, valued for the bank at $\max \left\{0, \pi_{1}-\alpha L-(1+r) K-Q(q)-C_{F}\right\}$, are seized by the bank.

\section{$\underline{\text { The third stage }}$}

In the third stage, the court is called into action if an accident occurred and the bank sued the firm for breach of contract, that is, for (alleged) insufficient care. If a suit is brought against the firm, the court finds the firm liable with probability $P(q, s)$. Therefore, in stage 3 , the bank realizes an expected net cash flow $E \Pi_{B}$ which depends on whether an accident occurred or not, on whether a suit is brought or not, on the findings of the court, and on the profits realized by the firm which determines the firm's capacity to avoid bankruptcy. Given our assumption of a standard Townsend-Gale-Hellwig loan contract, those profits are strictly observed by the bank and the court only if, following the court's decision, the firm is not fully reimbursing the bank

\footnotetext{
${ }^{16}$ Typically, banks do not charge firm specific interest rates but rather interest rates based on defined risk classes. Once the risk class of the firm is determined and the rate of interest fixed, the bank nevertheless will typically monitor carefully its financial interest in the firm.
} 
as instructed by the court, a situation which will indeed occur only if profits are low.

The total expected profit of the bank $E \Pi_{B}$ is therefore:

$$
\begin{aligned}
& E \Pi_{B}\left(\nu, q, \alpha, s ; K, r, \pi_{1}, \pi_{2}, \mu\right)=(1+r) K-C(\nu) \\
& -p(q)[(1-\nu)+\nu(1-P(q, s)](1-\alpha) L \\
& \quad-p(q) \nu P(q, s)(1-\mu)[0] \\
& \quad-p(q) \nu P(q, s) \mu\left[(1-\alpha) L-\max \left\{0, \pi_{1}-\alpha L-(1+r) K-Q(q)-C_{F}\right\}\right] .
\end{aligned}
$$

By assumption, the bank always receives a repayment of $(1+r) K$ and the cost of the bank's strategy (the probability $\nu$ with which it sues the firm) is borne whether an accident occurs or not. In the accident state, occurring with probability $p(q)$, the bank suffers a loss which may take three different values: (i) a loss of $(1-\alpha) L$ if it does not sue the firm for negligence, or if it sues the firm but the firm is found not guilty by the court, (ii) a loss of 0 if it sues the firm and the firm, when found guilty of negligence by the court, can reimburse the bank for the latter's share $(1-\alpha) L$ of the accident cost, or (iii) a loss of $\left[(1-\alpha) L-\max \left\{0, \pi_{1}-\alpha L-(1+r) K-Q(q)-C_{F}\right\}\right]$ if it sues the firm and the firm is found guilty of negligence by the court while profits are too low to allow the firm to fulfill its obligations, in which case the firm goes bankrupt and the bank gets only partial reimbursement of its share of the accident cost. The third term above indicates that the firm's expenses $(1+r) K-Q(q)-C_{F}$ as well as the liability expenses $\alpha L$ are covered in priority before the bank can get some of its liability expenses reimbursed. We further assume (see below) that when the firm goes bankrupt, the (operating) expenses $(1+r) K-Q(q)-C_{F}$ are covered before the firm's liability expenses $\alpha L$. We will concentrate our analysis to the more interesting case where, if the firm is sued and found guilty of negligence, situation (ii) would occur when profits are high $\left(\pi_{t}=\pi_{2}\right)$ while situation (iii) would occur when profits are low $\left(\pi_{t}=\pi_{1}\right)$.

Similarly, the total expected profit of the firm $E \Pi_{F}$ can be written as follows where $E \pi=$ 


$$
\begin{aligned}
\mu \pi_{1}+ & (1-\mu) \pi_{2}: \\
& E \Pi_{F}\left(q, \nu, \alpha, s ; K, r, \pi_{1}, \pi_{2}, \mu\right)=E \pi-Q(q)-(1+r) K \\
& -p(q)(1-\nu)\left[(1-\mu) \alpha L+\mu \min \left\{\alpha L, \pi_{1}-Q(q)-(1+r) K\right\}\right] \\
& -p(q) \nu(1-P(q, s))\left[(1-\mu)\left(\alpha L+C_{F}\right)+\mu \min \left\{\alpha L+C_{F}, \pi_{1}-Q(q)-C_{F}-(1+r) K\right\}\right] \\
& -p(q) \nu P(q, s)\left[(1-\mu)\left[L+C_{F}\right]+\mu \max \left\{0, \pi_{1}-Q(q)-C_{F}-(1+r) K\right\}\right] .
\end{aligned}
$$

The firm's extra payment in case of an accident can take three different forms: (i) if it is not sued for negligence by the bank, the firm pays its liability expenses $\alpha L$ if it can do so, that is if it can avoid bankruptcy (recall that bankruptcy can occur if profit is low, in which case the firm, being protected by limited liability, will not pay more than $\min \left\{\alpha L, \pi_{1}-Q(q)-(1+r) K\right\}$ ), (ii) if sued by the bank but found not guilty by the court, the firm is in a situation similar to the previous one except for the additional litigation cost $C_{F}$, (iii) if sued and found guilty, the firm reimburses the bank if it can (when profit is $\pi_{2}$ ), in which case it covers the full cost of the accident, or goes bankrupt and pays at most its assets value given by $\max \left\{0, \pi_{1}-Q(q)-C_{F}-(1+r) K\right\}$ to cover its liability expense $L$.

No decision is made in stage 3 . It is just recording the unfolding of the game. If no accident occurs, the firm repays $(1+r) K$. If an accident occurs but the bank does not sue the firm, then the latter repays $(1+r) K$ while the bank and the firm support their respective share of the cost of the accident. If an accident occurs and the bank sues the firm but the court finds the firm not guilty, then again the latter repays $(1+r) K$ while the bank and the firm support their respective share of the cost of the accident and the firm supports its litigation costs. Finally, if an accident occurs, the bank sues the firm, and the court finds the firm guilty of negligence, then the latter repays the loan $(1+r) K$ and covers its share of the accident costs $\alpha L$ plus the bank's share of the accident costs $(1-\alpha) L$ if profits are $\pi_{2}$, but repays only its net profits or assets value and goes bankrupt otherwise. 


\section{The second stage}

In the second stage, the bank and the firm, observing the government determined values of $\alpha$ and $s$, choose respectively $\nu$ and $q$ with the bank acting as first mover. ${ }^{17}$ Let us first consider the choice of safety care $q$ made by the firm as a function of the predetermined and observed values of $\alpha, s$ and $\nu$. The firm chooses the level of $q$ which maximizes its expected profit (2). Safety care activities affects the firm's expected profits through three channels: first, through the probability $p(q)$ of an accident; second, through the probability $P(q, s)$ of being found guilty of insufficient safety care or negligence if an accident occurs and the bank sues the firm; and third, through the cost $Q(q)$ the firm incurs for exerting safety care level $q$.

The firm chooses $q$ satisfying

$$
\frac{\partial E \Pi_{F}}{\partial q}=0
$$

giving rise to the best reply function $q\left(\nu \mid \alpha, s ; K, r, \pi_{1}, \pi_{2}, \mu, L, C_{F}, C_{B}\right)$ to the choice of $\nu$ made by the bank and of $\alpha$ and $s$ set by the government.

The expected return of the bank on its loan to the firm depends on the probability that it will sue the firm, on the probability that the firm will be found guilty if sued, and on the probability that the firm makes high profits. Since profits will not be observed unless the firm is not meeting its obligations to the bank, the probability that the bank will sue the firm in the accident state will not depend on the level of those profits. However, the expected benefits of suing depends on the expected capacity of the firm to avoid bankruptcy if found guilty by the court, that is, on the probability that realized profits are high. Hence, the bank chooses $\nu$ satisfying

$$
\frac{d E \Pi_{B}}{d \nu}=0
$$

considering the best reply care level function $q\left(\nu \mid \alpha, s ; K, r, \pi_{1}, \pi_{2}, \mu, L, C_{F}, C_{B}\right)$ of the firm. The solution to conditions (4) and (3) give us the second stage equilibrium values of variables $\nu$ and $q$

\footnotetext{
${ }^{17}$ This is hte natural assumption to make here. Indeed, banks typically determine their suing policy well in advance of determining a given firm risk class and therefore the terms of its loan. This policy must be assumed to be well known by firms.
} 
as functions of the government-determined variables $\alpha$ and $s$, namely: $\nu^{*}\left(\alpha, s ; K, r, \pi_{1}, \pi_{2}, \mu, L, C_{F}, C_{B}\right)$ and $q^{*}\left(\alpha, s ; K, r, \pi_{1}, \pi_{2}, \mu, L, C_{F}, C_{B}\right)$.

\section{The first stage}

We are now ready to define the government objective function (social welfare function) and characterize the optimal liability sharing value $\alpha^{*}$ and the optimal safety standard $s^{*}$. We will assume that the determination of the liability sharing formula involves a "political economy" cost $A(\alpha)$ if the government wants to implement a formula which moves away from the most acceptable formula from a social or political standpoint (assumed below to correspond to an equal liability sharing). The political correctness of the sharing formula is a social constraint that is quite realistic in the present context. The cost itself corresponds to the efforts necessary to convince the population of firms and banks of the desirability of the intended liability sharing formula.

The social welfare function $S W F$ is composed of the total gross benefits $W$ from allowing the firm to operate minus the expected cost of an accident, the cost of the firm's safety effort $q$, the cost of the bank's strategy $\nu$, the political cost of diverging from the most socially acceptable liability sharing, the firm's expected costs of litigation, and the cost of public funds necessary to cover that part of the cost of an accident which is covered neither by the firm nor by the bank. This last cost is proportional to the amount disbursed by the government in case of an accident under the assumption that the government will one way or another cover the cost of an accident (clean up costs and compensation of victims) not covered by the total payments made by the firm and the bank. This cost of public funds therefore depends on whether the bank sues the firm or not and in the former case on whether the firm is found guilty of negligence or not, and on whether the firm goes bankrupt or not following the occurrence of an accident and the 
decision of the court. The $S W F(\alpha, s)$ is given by:

$$
\begin{aligned}
& S W F(\alpha, s)= W-p\left(q^{*}\right) L-Q\left(q^{*}\right)-C\left(\nu^{*}\right)-A(\alpha) \\
&-\lambda p\left(q^{*}\right)\left[\left(1-\nu^{*}\right) \mu \max \left\{0, \alpha L-\left(\pi_{1}-(1+r) K-Q\left(q^{*}\right)\right)\right\}\right. \\
&\left.\quad+\nu^{*}\left(1-P\left(q^{*}, s\right)\right) \max \left\{0, \alpha L-\left(\pi_{1}-(1+r) K-C_{F}-Q\left(q^{*}\right)\right)\right\}\right] \\
&-\lambda p\left(q^{*}\right) \nu^{*} P\left(q^{*}, s\right) \mu \max \left\{0, \alpha L-\max \left\{0, \pi_{1}-(1+r) K-C_{F}-Q\left(q^{*}\right)\right\}\right\}
\end{aligned}
$$

where $\nu^{*}=\nu^{*}\left(\alpha, s ; K, r, \pi_{1}, \pi_{2}, \mu, L, C_{F}, C_{B}\right)$ and $q^{*}=q^{*}\left(\alpha, s ; K, r, \pi_{1}, \pi_{2}, \mu, L, C_{F}, C_{B}\right)$.

The government chooses the liability sharing factor $\alpha$ and the standard of care $s$ to maximize the social welfare function (5):

$$
\begin{aligned}
& \frac{\partial S W F(\alpha, s)}{\partial \alpha}=0 \\
& \frac{\partial S W F(\alpha, s)}{\partial s}=0
\end{aligned}
$$

The first-best solution

The above modelization clearly includes many institutional and informational constraints. We want to compare the solution obtained in the different cases (parameter values) not only between themselves but also with the first-best solution. The first-best solution is obtained under full information when the government chooses directly the level of safety effort $q$ and the value of $\alpha$ which maximizes social welfare. From the above, the first best least cost value of $\alpha$, namely $\alpha_{F B}$, is the one minimizing $A(\alpha)$. As for the optimal value of $q$, it corresponds simply to the value which minimizes the expected cost of an accident plus the cost of safety itself, that is the value $q_{F B}$ satisfies $p^{\prime}\left(q_{F B}\right) L+Q^{\prime}\left(q_{F B}\right)=0$. The cost of public funds $\lambda$ plays no role here since under full information, one can assume that $\lambda=0$. 


\section{A simplified realistic case}

Characterizing the best government strategy under the above institutional and informational constraints is a daunting, possibly impossible endeavor. Rather than pursue such a goal here, we will rather tackle a more limited but more tractable task, namely obtaining numerical best values of $\alpha$ in a simplified but realistic case. Clearly, this is a first step in a long journey. But we like to believe that it is a useful step if one aims at characterizing the complex set of forces which govern the intricate relationships underlying the determination of industrial/environmental accidents as seen for a social point of view.

We first present the numerical function we will use in the simulations and then show their properties in an attempt to convince the reader that the functions are sufficiently realistic and flexible to account for many significant real situations. Let us consider the following functions:

$$
\begin{aligned}
p(q) & \equiv p_{0}+\left(p_{M}-p_{0}\right)\left(1-e^{-\eta q}\right)\left\{\begin{array}{l}
=p_{0}, \quad \text { if } q=0 \\
\rightarrow p_{M}, \quad \text { as } q \text { becomes very large }
\end{array}\right. \\
P(q, s) & \equiv e^{-\delta(q / s)}\left\{\begin{array}{l}
=1, \quad \text { if } q=0 \\
=e^{-\delta}, \quad \text { if } q=s(P(s, s)=0.5 \text { if } \delta=\ln 2) \\
\rightarrow 0, \quad \text { as } q \text { becomes very large }
\end{array}\right. \\
Q(q) & \equiv z q^{b} \text { where } b>1 \text { and } z \text { is some positive parameter. } \\
C(\nu) & \equiv B \nu^{n} . \\
A(\alpha) & \equiv A(\alpha-0,5)^{a}
\end{aligned}
$$

The probability $p(q)$ of an accident is assumed to be between $p_{M}$ and $p_{0}$, where $p_{M}$ is the minimum unavoidable probability level representing the effect of all causal factors still at work 
when care is as large as it can be, and $p_{0}$ is the probability of an accident when the firm exerts no care $\left(p_{0}>p_{M}\right)$ with $p^{\prime}(q)=\eta\left(p_{M}-p_{0}\right) e^{-\eta q}<0$ and $p^{\prime \prime}(q)=-\eta^{2}\left(p_{M}-p_{0}\right) e^{-\eta q}>0$. Parameter $\eta$ measures the efficiency of care in reducing the probability of an accident.

The probability $P(q, s)$ that the court will find the firm guilty of insufficient care satisfies the following desirable and/or realistic properties, namely:

( $i$ ) it decreases at a decreasing rate with care $q$ (from 1 , when the firm exert no care, toward 0 , when the level of care becomes very large), so that both errors of type 1 (finding a firm with $q>s$ guilty of insufficient care) and errors of type 2 (finding a firm with $q<s$ not guilty) always remain possible, with

$$
\begin{aligned}
P(s, s) & =e^{-\delta} \\
P_{q}(q, s) & =-(\delta / s) e^{-\delta(q / s)}<0, \\
P_{q q}(q, s) & =(\delta / s)^{2} e^{-\delta(q / s)}>0 ;
\end{aligned}
$$

(ii) it increases with the safety standard $s$ with

$$
\begin{aligned}
P_{s}(q, s) & =\left(\delta q / s^{2}\right) e^{-\delta(q / s)}>0 \\
P_{s s}(q, s) & =\left[\left(\delta q / s^{2}\right)^{2}-(2 s \delta q) / s^{4}\right] e^{-\delta(q / s)},
\end{aligned}
$$

the latter being positive if $s<\frac{1}{2} \delta q$ [that is, the increase in the standard increases the probability of conviction, given the level of care $q$, at an increasing rate if $s$ is relatively small] and negative if $s>\frac{1}{2} \delta q$ [that is the increase in the standard increases the probability of conviction, given the level of care $q$, at a decreasing rate if $s$ is relatively large];

(iii) when $q=s$, it is constant at $e^{-\delta}$ for all $s$ (it is equal to 0.5 if $\delta=\ln 2$ );

(iv) moreover, it satisfies

$$
P_{q s}(q, s)=\left[\left(\delta / s^{2}\right)(1-\delta q / s)\right] e^{-\delta(q / s)}
$$

which is positive if $\delta q<s$ [that is the increase in the standard, given the level of care $q$, decreases the marginal efficiency of care in reducing the probability of conviction if $s$ is relatively large] and negative if $\delta q>s$ [that is the increase in the standard, given the level of care $q$, increases the marginal efficiency of care in reducing the probability of conviction if $s$ is relatively small]. 
Hence, for $\delta=\ln 2$, an increase in the standard $s$ increases the efficiency of safety care in reducing the probability of conviction iff the level of safety care $q$ is above $(\ln 2) s \approx 0.6931 s$, in which case an increase in the government determined standard would induce the firm to increase ceteris paribus its level of safety care. If the level of safety care $q$ is below that critical level, an increase in the government determined standard would induce the firm to decrease its safety care level, the reason being that it becomes more costly at the margin to avoid being convicted of negligence.

The cost of care function $Q(q)$ is increasing in $q$ at an increasing [decreasing] rate if $b>[<] 1$. So, parameter $b$ measures the economies/diseconomies of scale which may be present in care programs and activities. As to parameter $z$, it simply measures the linear cost efficiency of care.

The bank's litigation service cost function $C(\nu)$ increases in the probability that the bank will indeed sue a client firm responsible for an accident. To be able to do so efficiently, we assume that the bank has at all times an internal legal service whose size depends on $\nu$ and whose cost increases with $\nu$ at an increasing [decreasing] rate if $n>[<] 1$. Hence, parameter $n$ measures the economies/diseconomies of scale which may be present in the bank's litigation capacity. Parameter $B$ simply measures the linear cost efficiency of litigation capacity.

Finally, the political economy cost function of a given value of liability sharing is assumed to be minimized when liability is shared half and half between the parties, namely the bank and the firm here. Clearly, other "politically correct liability sharing" reference points could be envisaged.

The socially optimal liability sharing value $\alpha^{*}$ and the optimal safety standard $s^{*}$ can then be related to the parameters. We can run some comparative statics and illustrate the results in tables. That is what we do next. Among all possibilities, we will concentrate on the impact of the profitability of the firm (represented by parameter $\mu$, the probability that the project/firm generate a low level of profit or benefit), the cost of care activities (represented by parameter $z$ 
appearing in $Q(q)$, the cost of care function), the efficiency of care in reducing the probability of accident (represented by parameter $\eta$ appearing in $p(q)$, the probability of accident), the bank's cost of monitoring the firm's care activities (measured indirectly here by parameter $B$ appearing in the cost $C(\nu)$ incurred by the bank for maintaining a legal service, that is, a court litigation capacity as well as the expected costs of litigation and court procedures themselves), and finally the social cost of public funds (represented by parameter $\lambda$ ).

We first illustrate a base case scenario (Case 1) in Table 1.

Case 1. Parameters: $\pi_{1}=1000, \pi_{2}=5000, \mu=0.2, K=75, r=0.1, p_{0}=0.4, p_{M}=0.05$, $\delta=\ln (2), z=10, b=1.2, L=4000, \eta=0.2, C_{F}=0, B=1, n=2, \lambda=0.3, A=25$, $a=2$; four values of $s$, namely $6,10,18,28$. We obtain the following: $\alpha_{F B}=0.5, q_{F B}=13.17$, $p\left(q_{F B}\right)=0.0751$, and

[Insert Table 1: Base case scenario]

This base case scenario shows among other things that if the liability share of the firm increases, then as expected the bank chooses a lower probability of suing $\nu$, while the firm chooses a higher level of safety care, implying a lower probability of accident and a lower probability, for a given level of recommended care $s$, of being found guilty by the court in case the firm is taken to court by the bank. This translates into a level of social welfare which first increases and then decreases, under the combined opposite effects of a lower probability of accident and a higher cost of care activities. Table 1 shows also the effect on the equilibrium values of variables $\alpha, \nu$ and $q$ of different levels of care recommended by the government. The maximal social welfare is obtained when the government chooses $s=18$ and $\alpha=35 \%$, thereby inducing the bank to choose a relatively high probability of litigation of $91 \%$; those values of $\alpha, s$ and $\nu$ induce the firm to exert a relatively low level of care at 11.987 which implies a probability of accident of $8.2 \%$ and a probability of conviction for negligence of $63 \%$. It is interesting to note here that 
the levels $\alpha$ and $s$ are both lower than their first best values, which in this base case scenario are respectively $50 \%$ and 13.17 implying a first best probability of accident of $7.5 \%$. For low [high] values of $s$, the government sets the firm's liability share above [below] its full information first best level.

Case 2. Parameters: same as Case 1 except for $\mu$ which varies between 0.1 and 0.3 and $s$ which is fixed at $s=10$; we obtain the following: $\alpha_{F B}=0.5, q_{F B}=13.17, p\left(q_{F B}\right)=0.0751$, and

[Insert Table 2: variable $\mu$ ]

We look in this case at the effect of a lower profitability of the firm on the social welfare maximizing liability sharing (considering the level of recommended care fixed exogenously at $s=10)$ and equilibrium levels of litigation probability $\nu$ and care $q$. As the profitability of the firm/project decreases (as $\mu$ increases), liability is transferred from the firm to the bank, inducing the latter to increase the litigation probability. The net effect of these conflicting forces on the firm's incentives for care is to lower the level of care, thereby increasing the probability of accident and the probability of conviction for negligence. The latter probability remains lower than $50 \%$ though since the level of care chosen by the firm remains higher than the recommended level $s=10$. The incomplete information and partial control social welfare maximizing liability sharing between the firm and the bank falls mainly on the firm when the firm/project is very profitable ( $\mu$ small) but falls mainly on the bank when it is not ( $\mu$ large).

Case 3. Parameters: same as Case 1 except for $z$ which varies between 5 and 20 and $s$ which is fixed at $s=10$; we obtain the following: $\alpha_{F B}=0.5, q_{F B}$ variable, $p\left(q_{F B}\right)$ variable, and

[Insert Table 3: variable $z$ ]

We consider in case 3 the effect of increasing parameter $z$ which translates into higher cost of 
care activities. Although the first best level of liability sharing remains at $50 \%$, the first best level of care decreases with $z$ and therefore the probability of accident increases with $z$. The liability share of the bank increases with $z$, inducing it to increase the probability of litigation. The net effect of these three factors (higher $z$, lower $\alpha$, higher $\nu$ ) is to induce the firm to reduce its care level, thereby increasing the probability of accident and the probability of conviction for negligence which goes from under to over $50 \%$ as the level of care goes from higher to lower than the recommended level $s=10$.

Case 4. Parameters: same as Case 1 except for $\eta$ which varies between 0.1 and 0.3 ; we obtain the following: $\alpha_{F B}=0.5, q_{F B}$ variable, $p\left(q_{F B}\right)$ variable, and

[Insert Table 4: variable $\eta$ ]

We report in table 4 the results of a greater efficiency of care in reducing the probability of accident (higher $\eta$ ). The first best level of care, therefore the probability of accident, is sensitive to increases in $\eta$ as the higher efficiency of care could allow for a reduction in care and therefore the cost of care, with no cost in terms of probability of accident. We observe that the first best level of care indeed decreases with $\eta$. The combined effects of the increase in $\eta$ and the reduction in first best care level $q_{F B}$ is to decrease the first best probability of accident. As the efficiency of care increases, the incomplete information and partial control social welfare maximizing liability share of the firm decreases while the probability of litigation first increases and then decreases. The net effects on the equilibrium level of care is to reduce it while reducing also the probability of accident, which nevertheless remains higher than the decreasing the first best levels. As the level of care falls due to the increase in the efficiency of care, the probability of conviction in litigated cases increases.

Case 5. Parameters: same as Case 1 except for $B$ which varies between 0.5 and 2.5; we obtain the following: $\alpha_{F B}=0.5, q_{F B}=13.17, p\left(q_{F B}\right)=0.0751$, and 
[Insert Table 5: variable $B$ ]

We illustrate in this case the effects of increases in the cost of the bank's litigation capacity (including court costs). As the cost parameter $B$ increases, we observe that the incomplete information and partial control social welfare maximizing liability share of the firm increases while the probability of litigation by the bank drops, inducing a non-monotonic effect on the level of care exerted by the firm, as well as on the probability of accident, over the 0.5 to 1.5 range of $B$ values. The non-monotonicity in the social welfare function implies that there is a discontinuity in the optimal liability share of the firm which jumps suddenly to 1 somewhere between $B=2$ and $B=2.5$.

Case 6. Parameters: same as Case 1 except for $\lambda$ which varies between 0.1 and 0.5 ; we obtain the following: $\alpha_{F B}=0.5, q_{F B}=13.17, p\left(q_{F B}\right)=0.0751$, and

[Insert Table 6: variable $\lambda]$

Finally, we show in table 6 the results of increases in $\lambda$, the parameter representing the social cost of public funds. In the full information first best solution, the cost of public funds is irrelevant since it can be assumed to be 0 . Hence the first best level of $q$ is not sensitive to changes in $\lambda$. But under the informational and regulatory (control) constraints considered here, the efficiency of the taxation system is relevant insofar as the government may be called to cover part of both the clean up costs and the compensation of victims if an accident occurs. As Table 6 illustrates, increases in the social opportunity cost of public funds parameter $\lambda$ reduces the welfare maximizing value of the liability share of the firm, prompting the bank to increases its probability of litigation in case of accident. The lower liability share of the firm combined with the higher probability of litigation induces the firm to reduce its care activities while maintaining them at a level above the exogenously fixed recommended level $s=10$ in order to avoid too large an increase in the probability of conviction for negligence. Nevertheless, the probability of 
accident increases as well as the probability of conviction. A higher $\lambda$ induces the government to increase the liability share of the bank in order to avoid having to cover, at a higher social cost, the accident damages that the judgment-proof firm may impose on the government.

\section{Conclusion}

The importance of the debate about the choice of instruments in the environmental realm stems from the accelerating diffusion of environmentally risky production activities in modern industrial societies and the ensuing necessity to properly compensate the victims of accidents. To those elements, must be added the need to induce an efficient level of care by the potential injurers in contexts characterized by asymmetric information and partial control. Finally, and perhaps equally important, these issues and their analysis are important, in particular in the light of the challenging attempt by EC countries to design and implement a common environmental protection system.

The game being played by the four actors, namely governments, firms, banks, and courts, involves a set of complex interactions between them in the determination of industrial accidents. Although the modeling strategy we followed here is admittedly not the only possible way to make explicit the interactions between the four players, we believe that our modeling strategy captures many if not all the important characteristics, stemming from institutional and informational constraints, of a large number of real situations. The level of complexity in the interactions between the four players is significant, in particular in terms of the firm's limited liability, the asymmetric information on safety care levels chosen by firms and the profits made by firms, and the difficulty for courts to ascertain through the litigation process the level of care a firm has effectively exerted.

Nevertheless, we were able, through realistic numerical cases, to derive statements regarding the socially efficient government policies for industrial safety and the way those policies interact 
with the private interests of banks and firms as well as the imperfection of the court system. We characterized in particular the socially efficient liability sharing formula and standard of safety care, based on the interactions between the banks and the firms and on the efficiency of the courts in assessing the level of care exerted by the firm.

Our main results is to characterize, in a series of comparative statics exercises on a simplified but realistic functional example, the determination of the liability sharing between the firm and the bank. We showed that the incomplete information and partial control social welfare maximizing liability or financial responsibility share of the bank increases as the recommended level of care $s$ increases, as the profitability of the firm decreases, as the cost of care increases, as the efficiency of care increases, and as the social cost of public funds increases.

Hence, our results indicates or suggests that the government would be justified to implement an extended lender liability regime, ${ }^{18}$ or more generally a financial responsibility regime, or more specifically a reduced and more restrictive firm liability in favor of an increased and more extensive lender liability for environmental accidents, the higher the recommended level of care is, the more stringent and aggressive the courts are instructed to be with regards to firms' conviction for negligence, the less profitable the firm/project is (insofar as the firm is allowed to operate, that is, is globally profitable), the higher the cost of care is, the higher the efficiency of care is in reducing the probability of industrial/environmental accidents, the smaller the cost for the bank of maintaining a litigation capacity (including the court costs), and the higher the social cost of public funds is.

\footnotetext{
${ }^{18}$ See Boyer and Porrini (2004) for an analysis of factors favoring an extended lender liability regime over a regulatory regime subject to capture by the regulatees.
} 


\section{References}

[1] BALKENBORG D. (2001), "How Liable Should a Lender Be? The Case of Judgment-Proof Firms and Environmental Risk: Comment," American Economic Review 91(3), 731-738.

[2] BALKENBORG D. (2004), "On extended Liability in a Model of Adverse Selection," (in this book).

[3] BEARD R. (1990), "Bankruptcy and Care Choice," RAND Journal of Economics 21(4), 627-634.

[4] BOYD J., INGBERMAN D. (1997), "The Search of Deep Pocket: Is 'Extended Liability' Expensive Liability?" Journal of Law, Economics, and Organization 13(1), 233-258.

[5] BOYD J. (2002), "Financial Responsibility for Environmental Obligations: An Analysis of Environmental Bonding and Assurance Rules," in T. Swanson, Law and Economics of Environmental Policy, Research in Law and Economics Series, Elsevier.

[6] BOYER M., LAFFONT J.J. (1996), "Environmental Protection, Producer Insolvency and Lender Liability," in A. Xepapadeas (ed.), Economic Policy for the Environment and Natural Resources, Edward Elgar Pub. Ltd.

[7] BOYER M., LAFFONT J.J. (1997), "Environmental Risk and Bank Liability," European Economic Review 41, 1427-1459.

[8] BOYER M., LEWIS T.L., LIU W.L. (2000), "Setting Standards for Credible Compliance and Law Enforcement," Canadian Journal of Economics 33, 319-340.

[9] BOYER M., MAHENC P., MOREAUX M. (2004), "Environmental Protection, Consumer Awareness, Product Characteristics, and Market Power," (in this book).

[10] BOYER M., PORRINI D. (2001), "Law versus Regulation: A Political Economy Model of Instruments Choice in Environmental Policy," in A. Heyes (ed.), Law and Economics of the Environment, Edward Elgar Publishing Ltd., 409 pages. 
[11] BOYER M., PORRINI D. (2002), "The Choice of Instruments for Environmental Policy: Liability or Regulation?," in T. Swanson and R. Zerbe (eds.), An Introduction to the Law and Economics of Environmental Policy: Issues in Institutional Design, Research in Law and Economics Series, Elsevier, 540 pages.

[12] BOYER M., PORRINI D. (2004), "Modelling the Choice Between Regulation and Liability in Terms of Social Welfare," Canadian Journal of Economics 37(3), 590-612.

[13] DARI MATTIACCI G., PARISI F. (2004), "The Cost of Delegated Control: Vicarious Liability, Secondary Liability and Mandatory Insurance," International Review of Law and Economics 23, 453-475.

[14] DAUGHETY A.F., REINGAnUM J.F. (2003), "Markets, Torts and Social Inefficiency," Vanderbilt University.

[15] GOBERT K., POITEVIN M. (2004), "Environmental Risks: Should Banks be Liable?," (in this book).

[16] FAURE M. (2001), "The White Paper on Environmental Liability: Efficiency and Insurability Analysis," Environmental Liability 4, 188-201.

[17] FAURE M., GRIMEAUD D. (2000), "Financial Assurance Issues of Environmental Liability," Report for the European Commission.

[18] FEESS E., HEGE U. (2000), "Environmental Harm and Financial Responsibility," Geneva Papers of Risk and Insurance: Issue and Practice 25, 220-234.

[19] FEESS E., HEGE U. (2003), "Safety Monitoring, Capital Structure, and 'Financial Responsibility'," International Review of Law and Economics 23(3), 323-339.

[20] HEYES A. (1996), "Lender Penalty for Environmental Damage and the Equilibrium Cost of Capital," Economica 63, 311-323. 
[21] HIRIART Y., MARTIMORT D. (2004), "Environmental Risk Regulation and Liability under Adverse Selection and Moral Hazard," (in this book).

[22] HUTCHISON E., van’t VELD K. (2004), 'Extended Liability for Environmental Accidents: What You See Is What You Get', (in this book).

[23] INNES R. (2004), "Enforcement costs, optimal sanctions, and the choice between ex-post liability and ex-ante regulation," International Review of Law and Economics 24, 29-48.

[24] KORNHAUSER L.A. (1982), "An Economic Analysis of the Choice Between Enterprise and Personal Liability for Accidents," California Law Review 70, 1345-92.

[25] LEWIS T., SAPPINGTON D.M. (2001), "How Liable Should a Lender Be? The Case of Judgment-Proof Firms and Environmental Risk: Comment," American Economic Review 91(3), 724-730.

[26] NEWMAN H.A., WRIGHT D.W. (1990), "Strict Liability in Principal-Agent Model," International Review of Law and Economics 10, 219-231.

[27] PITCHFORD R. (1995), "How Liable Should a Lender Be?" American Economic Review $85(5), 1171-1186$.

[28] PITCHFORD R. (2001), "How Liable Should a Lender Be? The Case of Judgment-Proof Firms and Environmental Risk: Reply," American Economic Review 91(3), 739-45.

[29] POLINSKY M.A. (2003), "Principal-Agent Liability," Stanford University Law School Working Paper 258.

[30] SEGERSON K., TIETENBERG T. (1992), "The Structure of Penalties in Environmental Enforcement: an Economic Analysis," Journal of Environmental Economics and Management 23, 179-200.

[31] SHAVELL S. (1986), "The Judgement Proof Problem," International Review of Law and Economics 6, 45-58. 
[32] SHAVELL S. (1993), "The Optimal Structure of Law Enforcement," Journal of Law and Economics 36(1), 255-287.

[33] SHAVELL S. (2004), Foundations of Economic Analysis of Law, Harvard University Press, Cambridge, MA.

[34] SYKES A.O. (1984), "The Economics of Vicarious Liability," The Yale Law Journal 93, 1231-80.

[35] VISCUSI W.K. (1989), "Toward a Diminished Role fro Tort Liability: Social Insurance, Government Regulation, and Contemporary Risks to Health and Safety," Yale Journal of Regulation 6, 65-107.

[36] WOODFIELD A.E. (2004), "When Should the Bell Toll? The Economics of New Zealand's Debate on Indirect Liability for Internet Copyright Infringement," Review of Economic Research on Copyright Issues 1, 119-149. 
Table 1: Base case scenario

$\left[\alpha_{F B}=0.5, q_{F B}=13.17, p\left(q_{F B}\right)=0.0751\right]$

\begin{tabular}{|c|c|c|c|c|c|}
\hline$\alpha$ & $\nu$ & $q$ & $S W F$ & $p(q)$ & $P(q, s)$ \\
\hline \multicolumn{7}{|c|}{$s=6$} \\
\hline 0.05 & 0.918 & 10.343 & 3558.29 & 0.094 & 0.303 \\
\hline 0.25 & 0.898 & 10.830 & 3570.93 & 0.090 & 0.286 \\
\hline 0.45 & 0.869 & 11.215 & 3575.20 & 0.087 & 0.274 \\
\hline 0.65 & 0.820 & 11.611 & 3576.53 & 0.084 & 0.261 \\
\hline 0.75 & 0.776 & 11.814 & 3576.28 & 0.083 & 0.255 \\
\hline 0.95 & 0.445 & 12.251 & 3574.53 & 0.080 & 0.243 \\
\hline \multicolumn{7}{|c|}{$s=10$} \\
\hline 0.05 & 0.926 & 11.187 & 3567.00 & 0.087 & 0.461 \\
\hline 0.25 & 0.908 & 11.522 & 3576.91 & 0.085 & 0.450 \\
\hline 0.45 & 0.887 & 11.723 & 3578.30 & 0.084 & 0.444 \\
\hline 0.65 & 0.852 & 11.933 & 3577.48 & 0.082 & 0.437 \\
\hline 0.75 & 0.821 & 12.043 & 3576.45 & 0.081 & 0.434 \\
\hline 0.95 & 0.577 & 12.296 & 3573.94 & 0.080 & 0.426 \\
\hline \multicolumn{7}{|c|}{$* * s=18 * *$} \\
\hline 0.05 & 0.929 & 11.809 & 3572.97 & 0.083 & 0.635 \\
\hline 0.25 & 0.917 & 11.943 & 3578.52 & 0.082 & 0.631 \\
\hline 0.35 & 0.910 & 11.987 & 3579.03 & 0.082 & 0.630 \\
\hline 0.55 & 0.889 & 12.081 & 3578.27 & 0.081 & 0.628 \\
\hline 0.75 & 0.847 & 12.187 & 3575.98 & 0.081 & 0.625 \\
\hline 0.95 & 0.648 & 12.327 & 3573.31 & 0.080 & 0.622 \\
\hline \multicolumn{7}{|c|}{$s=28$} \\
\hline 0.05 & 0.932 & 12.001 & 3573.43 & 0.082 & 0.743 \\
\hline 0.25 & 0.922 & 12.084 & 3578.44 & 0.081 & 0.741 \\
\hline 0.35 & 0.915 & 12.110 & 3578.81 & 0.081 & 0.741 \\
\hline 0.55 & 0.896 & 12.167 & 3577.90 & 0.081 & 0.740 \\
\hline 0.75 & 0.858 & 12.236 & 3575.53 & 0.080 & 0.739 \\
\hline 0.95 & 0.676 & 12.338 & 3572.94 & 0.797 & 0.737 \\
\hline
\end{tabular}


Table 2: variable $\mu$

$\left[\alpha_{F B}=0.5, q_{F B}=13.17, p\left(q_{F B}\right)=0.0751\right]$

\begin{tabular}{|c|c|c|c|c|c|c|}
\hline$\mu$ & $\alpha$ & $\nu$ & $q$ & $S W F$ & $p(q)$ & $P(q, s)$ \\
\hline 0.10 & 0.65 & 0.855 & 12.310 & 3983.42 & 0.080 & 0.426 \\
\hline 0.15 & 0.55 & 0.873 & 12.016 & 3580.83 & 0.082 & 0.435 \\
\hline 0.20 & 0.45 & 0.887 & 11.723 & 3578.30 & 0.084 & 0.444 \\
\hline 0.25 & 0.35 & 0.898 & 11.432 & 3375.84 & 0.086 & 0.453 \\
\hline 0.30 & 0.30 & 0.903 & 11.189 & 3173.48 & 0.087 & 0.460 \\
\hline
\end{tabular}

Table 3: variable $z$

\begin{tabular}{|r|c|c|c|c|c|c|}
\hline$z\left(\alpha_{F B}, q_{F B}, p\left(q_{F B}\right)\right)$ & $\alpha$ & $\nu$ & $q$ & $S W F$ & $p(q)$ & $P(q, s)$ \\
\hline $5.0(0.5,16.417,0.063)$ & 0.45 & 0.860 & 14.885 & 3707.87 & 0.068 & 0.356 \\
\hline $7.5(0.5,14.513,0.069)$ & 0.45 & 0.876 & 13.008 & 3638.74 & 0.076 & 0.406 \\
\hline $10.0(0.5,13.171,0.075)$ & 0.45 & 0.887 & 11.723 & 3578.30 & 0.084 & 0.444 \\
\hline $12.5(0.5,12.137,0.081)$ & 0.45 & 0.895 & 10.752 & 3524.11 & 0.091 & 0.475 \\
\hline $15.0(0.5,11.298,0.087)$ & 0.40 & 0.907 & 9.934 & 3474.78 & 0.098 & 0.502 \\
\hline $17.5(0.5,10.591,0.092)$ & 0.40 & 0.912 & 9.292 & 3429.48 & 0.105 & 0.525 \\
\hline $20.0(0.5,9.983,0.098)$ & 0.35 & 0.920 & 8.714 & 3387.53 & 0.111 & 0.547 \\
\hline
\end{tabular}

Table 4: variable $\eta$

\begin{tabular}{|c|c|c|c|c|c|c|}
\hline$\eta\left(\alpha_{F B}, q_{F B}, p\left(q_{F B}\right)\right)$ & $\alpha$ & $\nu$ & $q$ & $S W F$ & $p(q)$ & $P(q, s)$ \\
\hline $0.10(0.5,18.709,0.104)$ & 0.65 & 0.865 & 16.056 & 3737.42 & 0.120 & 0.329 \\
\hline $0.15(0.5,15.433,0.085)$ & 0.55 & 0.877 & 13.524 & 3490.49 & 0.096 & 0.392 \\
\hline $0.20(0.5,13.171,0.075)$ & 0.45 & 0.887 & 11.723 & 3578.30 & 0.084 & 0.444 \\
\hline $0.25(0.5,11.536,0.070)$ & 0.40 & 0.890 & 10.439 & 3635.30 & 0.076 & 0.485 \\
\hline $0.30(0.5,10.297,0.066)$ & 0.40 & 0.888 & 9.456 & 3675.29 & 0.070 & 0.519 \\
\hline
\end{tabular}


Table 5: variable $B$

$\left[\alpha_{F B}=0.5, q_{F B}=13.17, p\left(q_{F B}\right)=0.0751\right]$

\begin{tabular}{|c|c|c|c|c|c|c|}
\hline$B$ & $\alpha$ & $\nu$ & $q$ & $S W F$ & $p(q)$ & $P(q, s)$ \\
\hline 0.5 & 0.40 & 0.938 & 11.746 & 3581.58 & 0.084 & 0.443 \\
\hline 1.0 & 0.45 & 0.887 & 11.723 & 3578.30 & 0.085 & 0.444 \\
\hline 1.5 & 0.55 & 0.845 & 11.777 & 3575.93 & 0.083 & 0.442 \\
\hline 2.0 & 0.60 & 0.809 & 11.793 & 3574.10 & 0.082 & 0.441 \\
\hline 2.5 & 1.00 & 0.000 & 12.413 & 3572.71 & 0.079 & 0.423 \\
\hline
\end{tabular}

Table 6: variable $\lambda$

$\left[\alpha_{F B}=0.5, q_{F B}=13.17, p\left(q_{F B}\right)=0.0751\right]$

\begin{tabular}{|c|c|c|c|c|c|c|}
\hline$\lambda$ & $\alpha$ & $\nu$ & $q$ & $S W F$ & $p(q)$ & $P(q, s)$ \\
\hline 0.10 & 0.75 & 0.821 & 12.043 & 3583.05 & 0.081 & 0.434 \\
\hline 0.20 & 0.60 & 0.863 & 11.879 & 3580.22 & 0.083 & 0.439 \\
\hline 0.30 & 0.45 & 0.887 & 11.723 & 3578.30 & 0.084 & 0.444 \\
\hline 0.40 & 0.30 & 0.904 & 11.571 & 3577.26 & 0.085 & 0.448 \\
\hline 0.50 & 0.30 & 0.904 & 11.571 & 3676.84 & 0.085 & 0.448 \\
\hline
\end{tabular}

